\title{
The Role of the Karaites in the Transmission of the Hebrew Bible and Their Practice of Transcribing It into Arabic Script
}

\author{
Geoffrey Khan \\ University of Cambridge, Cambridge, United Kingdom \\ gkıı@cam.ac.uk
}

\begin{abstract}
In the Middle Ages the Karaite Jews in the Islamic world used both Arabic and Hebrew script in their writings. They wrote not only Arabic texts in Arabic script but also many of their Hebrew Bibles in Arabic transcription. The Rabbanites, by contrast, used Hebrew script for writing both Arabic and Hebrew. This paper examines the association of the Karaites with the Masoretic transmission of the Hebrew Bible and the motivation for their transcribing the Bible into Arabic script. It is argued that the Arabic transcriptions reflect the polemical stance of the Karaites against the bases of scriptural authority of the Rabbinites and an advanced degree of rapprochement of the Karaites with the Muslim environment. They represent a convergence with the external form of the Muslim Arabic Qurān and also with the concepts of authority associated with the transmission of Muslim scripture.
\end{abstract}

\section{Keywords}

Karaites - Hebrew Bible - script - Arabic transcription - oral tradition

In the Middle Ages the Rabbanite Jews of the Middle East wrote Arabic predominantly in Hebrew script. The first such Judaeo-Arabic manuscripts are datable to the 9 th century C.E. Thereafter Judaeo-Arabic in Hebrew script continued to be used as a written language of Rabbanite Jews down to modern times. In the early Judaeo-Arabic texts from the gth and 1oth centuries the 
orthography of the Hebrew script was essentially that of Rabbinic Hebrew and Aramaic. By the 11th century, however, the orthography came to replicate in Hebrew script the spelling practices of Classical Arabic. The use of Hebrew script was taken over from the Hebrew and Aramaic literary tradition of the Jews. The language was changed but the traditional script continued. The different degrees with which the orthography of Arabic was adopted reflects the different degrees of rapprochement with Muslim literature and culture at the various periods. This rapprochement was at its greatest in the High Middle Ages (approximately 1oth-13th centuries). ${ }^{1} \mathrm{~A}$ large proportion of Arabic literary and documentary texts that have been preserved in medieval Jewish collections of manuscripts such as the Cairo Genizah collections and the Second Firkovitch collection are, therefore, written in Hebrew script.

At this period, Jewish scholars and scribes belonging to the Karaite movement of Judaism, however, frequently used Arabic script to write Arabic. The main reason for the use of Arabic rather than Hebrew script by the medieval Karaites seems to be that they did not feel themselves to be so rooted in the rabbinic literary tradition as the orthodox rabbanite Jews and were, consequently, more open to adopting literary and linguistic practices from the surrounding non-Jewish environment. ${ }^{2}$ It is important to note that there was not a complete assimilation to the literary Arabic culture by the Karaites, ${ }^{3}$ since during the High Middle Ages the Karaites wrote many of their Arabic manuscripts in Hebrew script. Indeed manuscript copies of the same text are sometimes extant in both scripts. There seems to have been a degree of free variation in the use of the two scripts at this period, which reflects an intermediate stage of cultural assimilation to the Islamic environment that had not reached completion. ${ }^{4}$

In the High Middle Ages (predominantly in the 1oth and 11th centuries C.E.) many Karaite scribes in the Middle East used Arabic script not only to write the Arabic language but also to write the Hebrew language. Such Hebrew texts in Arabic transcription were predominantly Hebrew Bible texts. These were

1 Blau and Hopkins, "On Early Judaeo-Arabic Orthography"; Khan, "Judeo-Arabic."

2 For this phenomenon see Drory, The Emergence ofJewish-Arabic Literary Contacts at the Beginning of the Tenth Century; Models and Contacts, 127-129.

3 Cf. the remarks of Stroumsa, "The Muslim Context of Medieval Jewish Philosophy," 56-57.

4 Khan, "The Medieval Karaite Transcriptions of Hebrew in Arabic Script"; idem, "On the Question of Script in Medieval Karaite Manuscripts." This free variation is clearly reflected by a letter published by Khan, "On the Question of Script in Medieval Karaite Manuscripts," written by the assistant of a Karaite scholar to a merchant who commissioned a copy of this scholar's work. The main purpose of the letter is to ask the addressee whether he would prefer his copy of the work to be written in Hebrew script or Arabic script. 
sometimes written as separate manuscripts containing continuous Bible texts. Some manuscripts in Arabic script contain collections of Biblical verses for liturgical purposes. Arabic transcriptions of verses from the Hebrew Biblical or individual Biblical Hebrew words were in many cases embedded within Karaite Arabic works, mainly of an exegetical nature, but also in works of other intellectual genres. Several Karaite Arabic works also contain Arabic transcriptions of extracts from Rabbinic Hebrew texts. ${ }^{5}$ The Karaites transcribed into Arabic script only texts with an oral reading tradition, as was the case with the Hebrew Bible and Rabbinic texts in the Middle Ages. The transcriptions reflect, in principle, these oral traditions. It is for this reason that the transcription of the Hebrew Bible represents the qere (the orally transmitted reading tradition of the text) rather than the ketiv (the written tradition). Other types of Hebrew text that were written by Karaites during the Middle Ages without an oral tradition, e.g., documents, commentaries, law books, were always written in Hebrew script. $^{6}$

Most of the known manuscripts containing Karaite transcriptions of Hebrew into Arabic script are found in the British Library, ${ }^{7}$ the Firkovitch collections of the National Library of Russia in St. Petersburg, ${ }^{8}$ and in the Cairo Genizah collections. ${ }^{9}$ These manuscripts emanate from Palestinian circles of Karaites or Karaites in Egypt who had migrated to Egypt from Palestine after the capture of Jerusalem by the Crusaders in 1099. The majority of them were written in the 1oth and 11th centuries. One of the transcriptions in the British Library (Or. 2554) has a colophon which states that it was written in Ramle in 395 A.H. (1004-1005C.E.). Several of the other manuscripts of the British Library corpus are written with the same form of script and orthography. These include Or. 2548 . Or. $255^{\circ}$, Or. $255^{1}$ fol. $31-56$, Or. $255^{1}$ fols. $57-101$, Or. 2581 a fols. 31-46. It would appear that these manuscripts all come from the pen of the

5 Tirosh-Becker, Rabbinic Excerpts in Medieval Karaite Literature.

6 Khan, "The Medieval Karaite Transcriptions of Hebrew in Arabic Script."

7 Hoerning, British Museum Karaite Mss; Khan, "Vowel Length and Syllable Structure in the Tiberian Tradition of Biblical Hebrew," 25-33; idem, "The Orthography of Karaite Hebrew Bible Manuscripts in Arabic Transcription."

8 Harviainen, "Karaite Arabic Transcriptions of Hebrew in the Saltykov-Shchedrin Public Library in St. Petersburg"; idem, "Karaite Bible Transcription with Indiscriminate Use of Tiberian Patah and Segol Vowel Signs"; idem, “A Karaite Bible Transcription with Indiscriminate Counterparts of Tiberian Qameș and Holam (Ms. Firkovitsh II, Arab.-Evr. 1)”; idem, "A Karaite Letter-for-Letter Transliteration of Biblical Hebrew"; "Ms Arab.-Evr. 2 of the Second Firkovitsh Collection, A Karaite Bible Transcription in Arabic Script.”

9 Khan, Karaite Bible Manuscripts from the Cairo Genizah. Gottheil "Some Hebrew Manuscripts in Cairo," 647, mentions the existence of an Arabic transcription of part of the book of Daniel in the Khedevial Library of Cairo (now the Egyptian Library). 
same scribe. The manuscripts were preserved down to modern times mainly in Egypt. This applies, of course, to the material from the Cairo Genizah. The British Library corpus comes from a collection of mainly Karaite manuscripts that were purchased by the library from the bookseller M.W. Shapira of Jerusalem in 1882. The main source of Shapira's manuscripts and also the manuscripts acquired by Abraham Firkovitch appears to have been the Karaite community of Cairo. A number of transcription fragments preserved in the Cairo Genizah were originally parts of manuscripts acquired by Shapira and now in the British Library, which shows that these British Library manuscripts must have come from Cairo. ${ }^{10}$ Some of the transcriptions in the British Library and Firkovitch collection may have been acquired also from the Karaite community of the Iraqi town of Hìt on the Euphrates. ${ }^{11}$

Most of the transcriptions of Biblical Hebrew reflect the Tiberian reading tradition, which is what is represented by the Tiberian vocalization signs that were created by the Tiberian Masoretes. The transcriptions, therefore, are an important source for the reconstruction of this reading tradition of Biblical Hebrew. $^{12}$ Many of the manuscripts are vocalized with Tiberian Hebrew vowel signs and accents. These conform on the whole to the standard Tiberian notation system. Various sporadic deviations from the Tiberian standard are, however, found in the vocalization and accents of some of the manuscripts. More systematic deviation is found in only a small number of manuscripts. Moreover, only in rare cases does the orthography of the transcriptions reflect deviations from the standard Tiberian tradition of pronunciation.

\section{Karaites and the Hebrew Bible}

In this section we shall look at the general engagement of the Karaites with the Hebrew Bible in the Middle Ages and their role in its transmission. This will lay the background for understanding the motivation for their practice of transcribing it into Arabic script.

\footnotetext{
10 Khan, Karaite Bible Manuscripts from the Cairo Genizah, 3-4.

11 Hoerning, British Museum Karaite Mss, v; Harviainen, "Abraham Firkovitsh, Karaites in Hit, and the Provenance of Karaite Transcriptions of Biblical Hebrew Texts in Arabic Script"; idem, "The Cairo Genizot and Other Sources of the Firkovich Collection in St. Petersburg"; idem, "Abraham Firkovich and the Karaite Community in Jerusalem in 1864."

12 For a description of our current knowledge of the Tiberian reading tradition based on the Karaite and other sources see Khan A Short Introduction to the Tiberian Masoretic Bible and Its Reading Tradition; idem, The Tiberian Pronunciation Tradition of Biblical Hebrew.
} 
Karaism arose in the early Islamic period as a movement within Judaism whose essential difference from Rabbanite Judaism consisted in their rejection of the legal authority of the oral law embodied in the Mishnah and Talmuds. The Karaites held that the basis of legal authority was the Bible. They shared the Bible in common with Rabbanite Jews and felt no need to create a separate version of Scripture that deviated from that of the Rabbanite Jewish tradition. This should be contrasted with the Samaritans, who broke away from Judaism and expressed their communal identity by adopting a different tradition of Scripture with its own distinct modifications and tendentious additions. The fact that the Karaites and the Rabbanites shared the same scripture meant that Karaites and Rabbanites had a common interest in carefully preserving the transmission of this scripture.

In the Middle ages all Jewish communities shared the same consonantal text of the Bible, but there were conspicuous differences across various communities regarding the reading traditions of the text, i.e. the ways in which the text was read aloud. This is reflected in the different vocalization sign systems that are attested in medieval manuscripts. These sign systems can be classified broadly into the Tiberian, Palestinian and Babylonian systems, though in each case the manuscripts attest to a number of variant sub-systems. The different vocalization systems do not represent any substantial differences in text among the different reading traditions, but they do reflect considerable differences in pronunciation and also, in many cases, differences in morphology.

The so-called standard Tiberian system of vocalization signs was regarded in the Middle Ages as the most prestigious and authoritative system. The reading tradition that the Tiberian vocalization reflected, known as the Tiberian reading tradition, was held to have similar prestige. The Tiberian vocalization sign system was developed in the early Islamic period by the Masoretes of Tiberias. The purpose of the sign system was to function as a written notation representing a tradition of reading that had been transmitted orally over many generations since the Second Temple Period. The activities of the Tiberian Masoretes came to an end in the 1oth century. Shortly thereafter the Tiberian reading tradition fell into oblivion among Jewish communities. The Tiberian sign system, however, which had been developed to represent the reading tradition was eventually adopted by all Jewish communities and it replaced the other sign systems. As a result the Tiberian signs came to be read with various local reading traditions, none of which were direct continuations of the Tiberian reading tradition.

It is important to note that the Karaites shared with the Rabbanites not only a common scripture but also shared with them the recognition of the Tiberian 
tradition of scripture as the most authoritative. It is for this reason that the Karaites had a particular interest in the Tiberian Masoretic tradition.

Karaites were closely associated with the Tiberian Masoretic tradition. This is demonstrated in a number of ways.

Many of the surviving monumental Tiberian Masoretic codices that were written towards the end of the Masoretic period in the 1oth and early 11th centuries contain inscriptions that indicate that the manuscript was dedicated to a Karaite community. ${ }^{13}$

Bible manuscripts often passed from Rabbanite into Karaite hands and vice versa and some of the manuscripts dedicated to Karaite communities may have been originally in the possession of Rabbanites. Such is the case with the Aleppo codex. This manuscript contained an inscription that indicates that it was written by the scribe Shlomo ben Buyāā and its vocalization and Masora were supplied by Aharon ben Asher and that a certain Israel ben Simhia of Bașra dedicated the manuscript to the Karaite community of Jerusalem. The first folio of the manuscript, however, contained a notice recording the fact that it was dedicated to the Rabbanite community of Jerusalem (על הערים 'השוכנים בעיר הקו'. icated to the Karaite community should be dated to the middle of the 11th century, about a hundred years after the manuscript was first produced by Ibn Buyāāa and Ben Asher. The notice at the beginning of the manuscript suggests that it was originally in Rabbanite hands and was subsequently purchased by the Karaite Israel ben Simha. This manuscript was transferred to Egypt after the capture of Jerusalem by the Crusaders, where it was placed in the Rabbanite synagogue of the Palestinians. When in Egypt, it was consulted by Maimonides, who pronounced it to be the most reliable model manuscript. ${ }^{15}$

13 Evidence of such dedications are found in the colophons of several of the Bible manuscripts in the second Firkovitch collection published by Kahle, Masoreten des Westens II, 56-77, e.g. no. 2 (Cod. 159, dedicated to the Jerusalem Karaite community, 937 A.D.), no. 3 (Cod. 10, dedicated to the Fustat Karaite community, eleventh century), no. 8 (Cod. 223, 225, dedicated to the Jerusalem Karaite community, 1017 A.D.), no. 11 (Cod. 25, 26, dedicated to the Fustat Karaite community, eleventh century), no. 12 (Cod. 94, dedicated to the Karaites of Egypt, 1100 A.D.), no. 13 (Cod. 34, dedicated to the Karaites of Fustat after the death of its owner, eleventh century). See also the colophons published by Poznanski, "Reshit hityashvut ha-qaraim b-Irushalayim," e.g. p. 115 (dedicated to the Karaites of Ramla, 1013A.D.).

14 The original inscriptions are now lost and survive only in copies, see Kahle, Masoreten des Westens II: das Palästinische Pentateuch Targum, die Palästinische Punktation, der Bibeltext des Ben Naftali, 7-12; Ofer, "M.D. Cassuto's Notes on the Aleppo Codex."

15 See Goshen-Gottstein, "The Authenticity of the Aleppo Codex," Penkower, "Maimonides and the Aleppo Codex" and Ofer, "M.D. Cassuto's Notes on the Aleppo Codex" for the evi- 
By the 16th century the manuscript had passed into the possession of the Rabbanite community of Aleppo. ${ }^{16}$

Some Tiberian Masoretic Bible codices that have inscriptions indicating their dedication to the Karaite community of Jerusalem in the 1oth or 11th century and were subsequently transferred to Egypt were held in the possession of the Karaite community of Cairo down to the present. This applies to several of the old Bible codices kept in the Karaite synagogue of Cairo, ${ }^{17}$ including the manuscript known as $\mathrm{C}_{3}$ (1oth century, no. 18 in Gottheil's list), ${ }^{18}$ and the socalled Cairo Codex of the Prophets (datable to the 11th century, the colophon indicating the date 895 C.E. being a copy of an earlier colophon). ${ }^{19}$

Although a dedication of a manuscript to a Karaite community does not necessarily mean that it originated in Karaite circles, the identification of the person who commissions the writing of the manuscript as a Karaite is proof that its production was a Karaite initiative. This is, indeed, the case with the codex Leningradensis (I Firkovitch B19a), which was commissioned by the Karaite Mevorakh ben Joseph ha-Kohen, who was, therefore, its first owner. ${ }^{20}$ According to the colophon of this manuscript, it was written by the scribe Samuel ben Jacob in the first decade of the 11th century (the various dating formulas correspond to dates between 1008 and 1010). Samuel is said to have added the vocalization, accents and masoretic notes based on 'the corrected and clear' ${ }^{21}$

dence that the Aleppo Codex was indeed the manuscript that Maimonides saw in Egypt. It is generally believed that this pronouncement of Maimonides ensured that the Ben Asher Masoretic tradition became the authoritative one in Judaism. A source from the eleventh century refers to the possibility of following either the school of Ben Asher or that of Ben Naftali, without any evaluation, see Eldar, "On Ben-Asher and Ben-Naftali." It is relevant to note, however, that the original vocalization and accents of the manuscript $\mathrm{C}_{3}$ of the Karaite synagogue in Cairo exhibited features of Ben Naftali's system but these features were corrected by Misha'el ben 'Uzz'iel in the early nth century to the reading of Ben Asher, see Gottheil, "Some Hebrew Manuscripts in Cairo" no. 18; Penkower, "A TenthCentury Pentateuchal Ms from Jerusalem (Ms C3)."

16 See the reconstruction of the history of the manuscript by Kahle, Masoreten Des Westens II, 3-12. and Ben-Zvi, "The Codex of Ben Asher."

17 Gottheil, "Some Hebrew Manuscripts in Cairo," 647.

18 Penkower, "A Tenth-Century Pentateuchal ms from Jerusalem (MS C3), Corrected by Mishael Ben Uzziel."

19 For the arguments regarding its dating, see Cohen, "Has the Cairo Codex of the Prophets Indeed Been Written by Moshe b. Asher?”; Glatzer, “The Aleppo Codex-Codicological and Paleographical Aspects," 250-259; Lipschütz, "Kitāb Al-Khilaf, the Book of the Hiillufim: Mishael Ben Uzziel's Treatise on the Differences between Ben Asher and Ben Napthali," 6-7.

20 Outhwaite, "Beyond the Leningrad Codex: Samuel b. Jacob in the Cairo Genizah."

21 Kahle interprets the term מבואר as 'supplied with Masora'. 


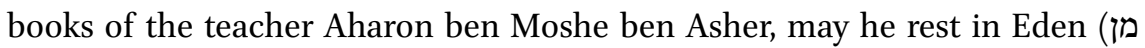
(הספרים המוגהים והמבואר אשר עשה המלמד אהרן בן משה בן אשר נוחו בגן עדן (I). This, therefore, was a copy of a Tiberian Masoretic manuscript and was not itself produced by a Tiberian Masorete. Jacob ben Samuel also wrote a Bible manuscript preserved in the Karaite synagogue in Cairo, no. 14 in the list of Gottheil. ${ }^{22}$ The colophon indicates that this was commissioned by David ben Yeshu'a ha-Levi who presented it to the Karaite community of Cairo. So the production of this manuscript, too, appears to have been a completely Karaite initiative. ${ }^{23}$

The dedication inscription of the Aleppo codex indicates that when this carefully produced model manuscript that was written by Tiberian Masoretes came into the possession of a Karaite community, it was made available also for Rabbanites to consult in order to check readings: ואם יחפוץ איש מכל זרע ישראי

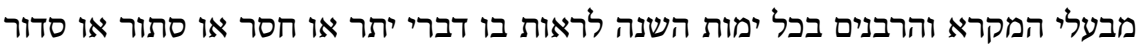

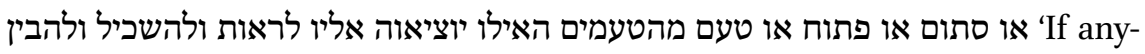
body of the seed of Israel, from among the Karaites or the Rabbanites, wishes on any day of the year to see in matters relating to full or defective orthography, what is disordered or ordered, closed or open sections, or one of the accents, they should bring it out for him to see and check and so gain understanding. ${ }^{24}$

Some scholars who are known to have been Karaites can be shown to have been closely associated with the Tiberian Masoretic tradition. This applies to the Karaite grammarians who were active in Jerusalem towards the end of the Masoretic period. The two most important Karaite grammarians in this respect are 'Abū Ya'qūb Yūsuf ibn Nūh (known in Hebrew as Joseph ben Noạ̣, second half the tenth century) and 'Abū al-Faraj Hārūn ibn Faraj (first half of the eleventh century). ${ }^{25}$

\footnotetext{
22 "Some Hebrew Manuscripts in Cairo."

23 Jacob ben Samuel also wrote the Bible manuscript no. 27 of Gottheil's list, which was preserved in the Karaite synagogue, for a certain Yahya ben Jacob. For our current state of knowledge concerning manuscripts written by Jacob ben Samuel and recent discoveries see Phillips, "A New Codex from the Scribe behind the Leningrad Codex: L17."

24 Kahle, Masoreten des Westens II, 4-5; Ofer, "M.D. Cassuto's Notes on the Aleppo Codex," 288-289.

25 For details of the Karaite grammarians of Jerusalem and their grammatical thought see Khan, "The Contribution of the Karaites to the Study of the Hebrew Language"; idem, "The Medieval Karaite Tradition of Hebrew Grammar"; idem, The Early Karaite Tradition of Hebrew Grammatical Thought; Khan, Gallego and Olszowy-Schlanger, The Karaite Tradition of Hebrew Grammatical Thought in Its Classical Form; Vidro, "Verbal Morphology in the Karaite Treatise on Hebrew Grammar Kitāb Al-'Uqūd Fī Tașārīf al-Lug̉a al-'Ibrāniyya”; idem, Verbal Morphology in the Karaite Treatise on Hebrew Grammar.
} 
According to Ibn al-Hītī, who wrote a chronicle of Karaite scholars, Yūsuf ibn Nūḥ had a college (dār li-l-'ilm) in Jerusalem, which appears to have been established around the end of the tenth century. ${ }^{26}$ 'Abu al-Faraj Hārūn belonged to this college of Karaite scholars. Some sources refer to Yūsuf ibn Nūh as 'Abū Ya'qūb Yūsuf ibn Bakktawaih (or Baǩtawi), or Joseph ben Bakktawaih. Bakntawaih may have been the Iranian equivalent of the name Nūh or Noah (cf. Persian bakt 'fortune, prosperity'). Inscriptions on some of the early Masoretic Bible codices that dedicate the manuscript to the Jerusalem Karaite community give instructions for them to be deposited in the haser ('compound') of Joseph ben Baktawaih, which is likely to be identical with Ibn Nūh's college, referred to by Ibn al-Hītì by the corresponding Arabic term $d \bar{a} r .{ }^{27}$ The manuscript $\mathrm{C}_{3}$ of the אני מישאל בן עזיאל בן יוסף בן Karaite synagogue in Cairo ${ }^{28}$ contains the inscription 'I Misha’el ben 'Uzz’iel ben Yoseph ben Hillel checked this holy Torah in the enclosure of ben Bakhtawaih, may God have mercy on him.' This indicates that it must have been kept in ben Bakhtawaih's enclosure, where the scholar Misha'el ben 'Uzz'iel consulted it.

The close relationship of the early generation of Karaite grammarians in the tenth century, such as Ibn Nūh, to the Tiberian Masoretic tradition is reflected by the methodology and disciplinary structure of their works. The grammatical work of Ibn Nūh that has come down to us is a grammatical commentary on the Bible known as the Diqduq. The term diqduq does not have the sense here of 'grammar' as an independent discipline, but rather as the 'study of the fine details of scripture'. A central feature of Ibn Nūh's method of presentation is the explanation as to why a word has one particular form rather than another. This often involves comparing closely related forms that differ from the form that is under investgation only in small details. This may be compared to the practice of the Masoretes to collate words that were similar in form but dif-

26 For the text of Ibn al-Hītī see Margoliouth, "Ibn Al-Hītī's Arabic Chronicle of Karaite Doctors," 438-439. Ibn al-Hītī was writing in the fifteenth century. For the background of Ibn Nūḥ's college, see Mann, Texts and Studies, vol. 2, 33-34.

27 Cod. 159 of II Firkovitch collection, dedicated 937A.D. (Kahle, Masoreten des Westens II, no. 2, p. 6o), Cod. 225 of II Firkovitch collection, dedicated 1017 A.D. (Kahle, ibid., no. 8, p. 67). The inscription in cod. 159 relating to the compound of Joseph ben Baktawaih is separate from the main dedication, which is dated 937A.D. Since Yūsuf ibn Nūh/Joseph ben Baktawaih is known to be active in the second half rather than the first half of the 1oth century, the inscription relating to his compound must have been added later. The inscriptions in both manuscripts add the blessing ירחמהו יי' 'may God have mercy on him' after the name Joseph ben Baktawaih, which indicates that they were written after his death.

28 Gottheil, "Some Hebrew Manuscripts in Cairo" no. 18; Penkower, "A Tenth-Century Pentateuchal Ms from Jerusalem (MS $\left.\mathrm{C}_{3}\right)$." 
fered only in details. This was a central feature of the masoretic method and lists recording these collations are found throughout the masoretic notes that were attached to Bible codices. The purpose of this was to draw attention to fine details of form to ensure that they were preserved in the transmission of Scripture. Collations of two closely related forms of word were also compiled in independent masoretic treatises, such as 'Oklah we-' ${ }^{\prime} k l a h .{ }^{29}$ By the tenth century, the Masoretes also compiled treatises that formulated rules for the occurrence of some of these fine distinctions in form with regard to vowels and accents. The most famous work of this kind is the Diqduqe ha-Te'amim 'The rules of the details of the accents', which was compiled in the first half of the tenth century by Aharon ben Asher. ${ }^{30}$

Apart from these parallels in methodology, another feature that reflects the close relationship of Ibn Nūh's work to Masoretic activities is the fact that Ibn Nūh's grammatical comments relate mainly to morphology, with some consideration of syntactic issues. They make only very marginal reference to issues of vocalization and accents. They, therefore, complement the Masoretic treatises, indicating that the early Karaite grammarians were developing the Masoretic tradition rather than setting up an independent discipline.

This complementary relationship between the Masorah and grammar which characterizes the early Karaite grammatical tradition contrasts with the scope of the grammatical work composed by Saadya Gaon in the tenth century. After leaving Egypt, Saadya spent a few years in Tiberias studying among the Masoretes. According to Dotan ${ }^{31}$ he composed his grammar book (Kitāb Fașịh Luggat al-Tbrāniyyin "The Book of the Eloquence of the Language of the Hebrews') while he was in Tiberias during the second decade of the tenth century. Unlike the Diqduq of Ibn Nūh, the grammatical work of Saadya does not complement the work of the Masoretes but rather incoporates numerous elements from it. The surviving sections of the work include not only treatments of grammatical inflection and word structure but also several chapters relating to the Tiberian reading tradition. The material for some of these has clearly been incorporated from the Masoretic tradition and direct parallels can be

29 The treatise 'Oklah we-'Oklah is named after the first two words of the first list ('eating' [ISam. 1:9] 'and eat' [Gen. 27:19]), which enumerates pairs of words, one occurring with the conjunctive waw and the other without it. For a general discussion of the background of the text see Yeivin, Introduction to the Tiberian Masorah, 128-131. An edition of the text based on the best manuscripts has been made by Díaz Esteban, Sefer 'Oklah Wě-'Oklah, and Ognibeni, La Seconda Parte del Sefer 'Oklah We'Oklah.

30 The definitive edition of this text is by Dotan, The Diqduqé Hatțěamim.

31 Dawn of Hebrew Linguistics, 33-40. 
found in the extant Masoretic treatises such as Diqduqe ha-Téamim. ${ }^{32}$ Saadya refers to the accents on various occasions. Dotan, indeed, suggests that one of the missing chapters from Saadya's work may have been concerned specifically with accents. We may say that Saadya's grammar book is not a product of collaboration with the Masoretes or a complementary expansion of the scope of Masoretic teaching, as is the case with the Diqdquq of Ibn Nūh, but rather was intended as standing separate from the Masoretic tradition.

The complementary relationship of Ibn Nūḥ's grammatical work with Masoretic activity is further shown by an early text published by Allony ${ }^{33}$ that contains a list of technical terms for the various aspects of Biblical study. These are described in the text as diqduqe ha-miqra, which has the sense of 'the fine points of Scripture established by detailed investigation. The list includes masoretic, grammatical and hermeneutical terms. These correspond closely to the terminology and concepts of Ibn Nūh's Diqduq. The range of the topics of analysis denoted by the terms also parallels the scope of analysis that is found in the Diqduq, though, as we have remarked, the focus of the Diqduq is more on the grammatical and hermeneutical aspects than on the masoretic. It is more accurate to say that the masoretic works and Ibn Nūh's Diqduq combined cover the range of topics contained in the list. The Masora and Masoretic treaties, on the one hand, and the grammatical work of Ibn Nūh, on the other, complement each other to establish the diqduqe ha-miqra. This list was not intended primarily as a foundation for the study of grammar per se, but rather as a methodology for establishing the correct interpretation of Scripture. It appears to reflect the scope of the scholarly work that developed around the core Masoretic activities, in which the grammatical work of Karaite scholars such as Ibn Nūh play an integral role.

Allony, in his edition of this list of technical terms, claimed that it was of Karaite background. One should be cautious, however, of being too categorical on this issue. Certain details of its content suggest that it was composed in the early Islamic period. It would, therefore, come from a period when Karaism was in its embryonic stages of development. The main evidence that Allony cites for its being a Karaite work is the reference in the text to the 'masters of the reading of the Bible' (ba'ale ha-miqra). This term was used in some texts in the Middle Ages to designate Karaites. ${ }^{34}$ It is found, however, already in Rabbinic

32 Dotan, ibid., 34-36.

33 "Rešimat Munahim Qara'it."

34 It is used frequently in this way in the inscriptions on the Bible codices discussed above and also in the writings of medieval Karaite scholars such as Salmon ben Yeruham and Judah Hadassi. 
literature in the sense of 'those who study only the Bible and not the Mishnah or Gemara: ${ }^{35}$ It should be noted, moreover, that in masoretic texts it is sometimes used as an epithet of the Masoretes, who were professionally occupied with the investigation of the Bible. ${ }^{36}$ The contents of the list were incorporated by a number of later authors into their works. These included not only Karaites but also Rabbanites, such as Dunaš ben Labrat. ${ }^{37}$

'Abū al-Faraj Hārūn, who was based at the college of Karaite scholars, is said by Ibn al-Hìtì to have been the student of Ibn Nūh. The content of 'Abū al-Faraj's work, however, is very different from that of Ibn Nūh, mainly because it conforms more closely to the theories of grammar propounded by the mainstream Bașran school of Arabic grammar. The Arabic works of 'Abū al-Faraj, nevertheless, still maintain the complementarity between grammar and Masora, which is characteristic of the work of Ibn Nūh, in that they are by and large restricted to morphology and syntax with minimal consideration of vocalization and accents, which reflects the close relationship of 'Abū al-Faraj to the Masoretic tradition, again contrasting with the grammatical work of Saadya.

Moving now from the para-masoretic discipline of Karaite grammar to core masoretic activities, we are able to identify the authors of some of Masoretic treatises at the end of the Masoretic period in the 11th century as Karaite. 'Abū al-Faraj Hārūn himself wrote a treatise on the biblical reading known as Hidāyat al-Qāri' 'Guide for the Reader', which described the pronunciation of consonants and vowels and the principles of the accents. ${ }^{38}$ This complemented his grammatical works on morphology and syntax. ${ }^{39}$ He states that his sources for the work were earlier masoretic treatises and the pupils of the writers of these earlier treatises (תלאמידהם), ${ }^{40}$ which indicates that he had access to an oral tradition of instruction in the Tiberian reading. Another scholar working in the Karaite college founded by Yūsuf ibn Nūḥ/Joseph ben Baktawaih was Misha'el ben 'Uzzi'el. As we have seen above, in an inscription in the manuscript $\mathrm{C}_{3}$ of the Karaite synagogue in Cairo he writes that he checked the manuscript in the 'enclosure of ben Baktawaih'. This implies that he was a Karaite belonging to the circle of scholars in the Karaite college, most

\footnotetext{
35 Cf. Bacher, Die Exegetische Terminologie, 118.

36 E.g. Baer and Strack, Dikduke Ha-Téamim, xxxviii.

37 Tešubot de Dunaš ben Labrat, ed. Sáenz-Badillos, $15^{*}$.

38 Eldar, The Study of the Art of Correct Reading, Khan, The Tiberian Pronunciation Tradition of Biblical Hebrew, vol. 2.

39 Khan, "The Relationship of 'Hidāyat al-Qāri' to the Karaite Grammatical Tradition."

40 Khan, The Tiberian Pronunciation Tradition of Biblical Hebrew, vol. 2. Long version of Hidāyat al-Qāri', §II.L.o.9.
} 
likely contemporary with 'Abū al-Faraj Hārūn in the first half of the nth century. This is almost certainly the same Misha'el ben 'Uzz'iel who composed a Masoretic treatise concerning the differences between the leading Masoretes Aharon ben Asher and Moshe ben Naftali, known as Kitāb al-Kilaf 'The book of differences'.41 Fragments are extant also of a book of differences between the Masoretes written at roughly the same period by the Karaite Levi ben Yefet, also known as Levi ben al-Hasan, who was the son of the Karaite translator and exegete Yefet ben 'Eli. ${ }^{42}$

Several modern scholars have argued that some of the Masoretes themselves were Karaites, in particular Aharon ben Asher, who was one of the most prominent Masoretes towards the end of the Masoretic period in the 1oth century. In all cases, however, the arguments are based on indirect or doubtful evidence.

Pinsker ${ }^{43}$ says that all the Masoretes should be 'suspected' of being Karaites since they spent their time occupied with vocalization and accents of the Bible and there is no evidence that they showed any interest in the Talmud.

Klar ${ }^{44}$ identified the name 'Ben Asher' in a manuscript at the head of Saadya Gaon's polemical poem against the Karaites אשא משלי, and claimed that this proved that Saadya's Karaite opponent, against whom the poem was addressed, must have been the Masorete Aharon ben Asher. Zucker ${ }^{45}$ and Dotan ${ }^{46}$ have convincingly argued against this on the grounds of the contents of poem, which are inconsistent with such an identification, especially the attribution of antiTalmudic pronouncements to the opponent.

Some scholars ${ }^{47}$ have claimed to be able to identify Karaite doctrines in Masoretic treatises attributed to Aharon ben Asher and in the extant 'poem of the vine' that is attributed to his father, Moshe ben Asher, but again these are not at all clear and have also been rebutted by Zucker ${ }^{48}$ and Dotan. ${ }^{49}$ More recently Zer ${ }^{50}$ has argued that evidence for the Karaite persuasion of Aharon ben Asher can be found in the masoretic notes that he wrote in the Aleppo codex. One of Zer's central arguments is based on the masoretic note

\footnotetext{
41 Lipschütz, "Kitāb Al-Khilaf the Book of the Hillufim"; Kitāb Al-Khilaf.

42 Lipschütz, "Kitāb Al-Khilaf the Book of the Hillufim," 3.

43 Lickute Kadmoniot. Zur Geschichte des Karaismus und der karaïschen Literatur, 34.

44 Mehqarim ve-Tyyunim, 276-319.

45 "Against Whom Did Se'adya Ga'on Write the Polemical Poem 'Essa Meshali'?"

46 Ben Asher's Creed.

47 E.g. Graetz, "Die Anfänge der Vocalzeichen im Hebräischen," 366; Klar, Mehqarim veTyyunim, 276-319.

48 "Against Whom Did Se'adya Ga'on Write the Polemical Poem ‘Essa Meshali'?"

49 Ben Asher's Creed.

$50 \quad$ "Was the Masorete of the Aleppo Codex of Rabbinite or Karaite Origin?"
} 


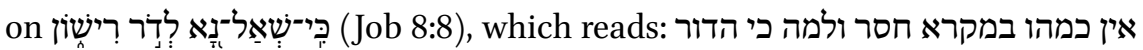

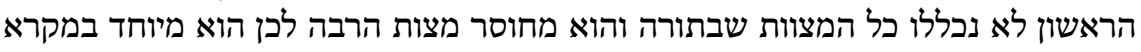

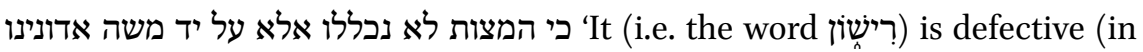
orthography) unlike any (other occurrence of the word) in the Bible. Why? Because in the first generation all the commandments that are in the Torah were not completed, but it lacked many commandments, therefore it (i.e. the

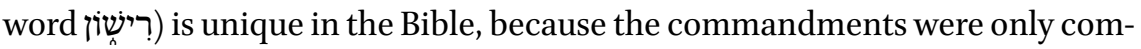
pleted by the hand of Moshe, our master.' Zer points out that Karaites held this doctrine of the gradual revelation of commandments. Erder ${ }^{51}$ has presented various medieval Karaite sources that adhere to this doctrine. There is, however, some degree of variation of thought in these sources. Moreover, the view that commandments were given before Sinai is also found in the Talmud and in the writings of Maimonides, although Maimonides maintains that only those revealed at Sinai are obligatory. ${ }^{2}$ The use of differences in full and defective orthography of the ketiv as a source of interpretation is a practice found in Rabbinic texts, ${ }^{53}$ but it was not approved of by many medieval Karaites, who regarded the reading tradition (qere) to be the only legitimate source of textual authority. This is stated explicitly by al-Qirqisānī. ${ }^{54}$ It would, therefore, be highly unusual for a Karaite Masorete to use this type of hermeneutics.

Yeivin ${ }^{55}$ draws attention to a peculiarity in the vocalization of the Aleppo codex whereby in words that have a qere with inversion of the letters of the ketiv, the vocalization signs are not marked in the order required by the qere but rather are marked on the letters of the ketiv in a different order from the word of the qere that they are intended to represent. In Ezek. 36:14, for example, the ketiv תכשלי has a qere with inversion of letters, which the codex Leningraden-

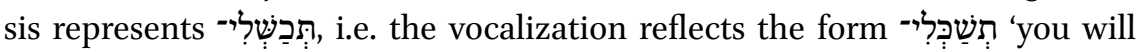
[not] bereave' with the vowels in the correct order. The Aleppo codex, how-

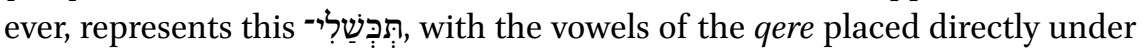
the consonants of the form of the qere, with the result that the vocalization does not follow the order of vowels in the qere. Another example, this time a word with an accent, is in 2 Sam. 20:14, where the ketiv ויקלהו is represented by

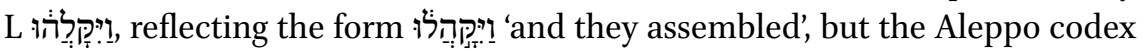

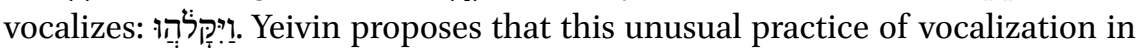
the Aleppo codex reflects the view of the vocalizer that the vocalization and

$51 \quad$ "Early Karaite Conceptions."

52 Erder, "Early Karaite Conceptions," 137-139.

53 Goldberg, "The Rabbinic View of Scripture."

54 The relevant passages of al-Qirqisānī's work are discussed below.

55 "The Vocalization of Qere-Kethiv in A." 
accents were given at Sinai and were as old as the letters, with the consequence that the vowel signs were considered to be bound to the letters, i.e. if the letters are inverted, then the vocalization and accents were also inverted. Yeivin argues that this demonstrates that the vocalizer, i.e. Aharon ben Asher, was a Karaite, because the Karaites held the view that the vowels and the accents were given at Sinai. There is not, however, clear evidence of such a doctrine being held by the Karaites, to my knowledge, before Judah Hadassi (12th century), who states in his work Eškol ha-Kofer that the original Tablets given to Moses at Sinai had the vowels and accents 'for without the five vowels which are [represented by] the vowel signs a word could not be articulated nor could it be understood without the pronunciation of the vowels and accents. ${ }^{56}$ Earlier Karaites, however, did not express this doctrine. The Karaite list of grammatical terms published by Allony ${ }^{57}$ and dated by him to the Masoretic period only states ואותיות בנקודות ונקודות במסורות letters are [known] by vowels and the vowels are known by the masorot'. One cannot infer from this, as Allony does, ${ }^{58}$ that the author believes that the original Tablets were inscribed with the vowels and accents. The Karaite al-Qirqisāni (1oth century) states that the vowels are subordinate to the letters and are not part of the 'holy' script. ${ }^{59}$ At approximately the same period as Hadassi expressed the doctrine that the vowel points were given to Moses at Sinai, the same view was expressed by several Rabbanites, e.g. David Qimhị (Sefer Miklol, ed. Lyck, 1862, 73) and Moses ben Isaac of England. ${ }^{60}$ There is no evidence that the doctrine was specifically Karaite. It seems to have arisen due to the chronological distance between the scholar in question and the period in which the pointing and accentuation were first developed rather than due to any doctrinal Tendenz.

We may conclude, therefore, that there is no incontrovertible evidence that Aharon ben Asher or his family were Karaites. The medieval sources refer to several generations of Masoretes, some of them belonging to the same family. They indicate that the family of Aharon Ben Asher had been involved in masoretic activies over five generations. Aharon Ben Asher lived in the 1oth century and so Asher 'the elder', who is stated to be the great-great-grandfather of Aharon, is likely to have lived in the second half of the eighth century

\footnotetext{
כי בלי חמשת הקולות שהם מלכי הנקוד לא תולד המלה ולא תעמוד בפה ולא יודע מה היא כי 56

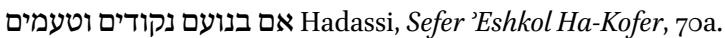

57 "Rešimat Munahim Qara’it me-ha-Me’a ha-Šeminit."

58 ibid., 333, 349 .

59 Kitāb al-'Anwār w-al-Marāqib, ed. Nemoy, 554.

6o Cf. Bacher Die Anfänge Der Hebräischen Grammatik, 83-84. and Chiesa, The Emergence of Hebrew Biblical Pointing, 5-8.
} 
C.E., before the emergence of Karaism on the historical scene in Palestine. ${ }^{61}$ Some of the Masoretes, furthermore, were closely associated with the Rabbanite Jewish authorities, e.g. Pinhas Rosh ha-Yeshiva ('head of the academy'), who lived in the ninth century, and 'Ahiyyahu ha-Kohen he-Haver ('member of the academy'). ${ }^{62}$ The 'academy' (yeshiva) was the central body of Rabbanite Jewish communal authority in Palestine. Some close parallels to the format and phraseology of the masoretic notes can, in fact, be found in Midrashic literature composed before the Islamic period (Martín Contreras 1999, 2002, 2003). As has already been remarked above, there are references already in Rabbinic literature to the existence of 'Bible scholars' (ba'ale ha-migra), who are likely to the forerunners of the Masoretes.

All this suggests that Karaite scholars joined forces with an existing stream of tradition of 'Bible scholarship' in Rabbanite Judaism, enhancing it and developing it. The evidence suggests that this took place mainly towards the end of the Masoretic period in the second half of the 1oth century and the 11th century. Their particular contribution to the Tiberian Masoretic tradition was (i) to sponsor the safekeeping of the model Masoretic codices produced by the Masoretes and, particularly in the 11th century after the cessation of the activities of the Tiberian Masoretes, the production of accurate copies of Masoretic Bibles; (ii) the production of some Masoretic treatises and (iii) the development of the para-masoretic philological activity of grammar.

As we have seen, the inscriptions on several of the Bible codices that were dedicated to Karaite communities indicate that they were to be used as models for scribes to consult. The inscription on the Aleppo codex indicates that the manuscript should be made available to both Karaites and Rabbanites for this purpose. Several of the inscriptions also indicate that the codices should be used for liturgical reading by the Karaite communities on sabbaths and fes-

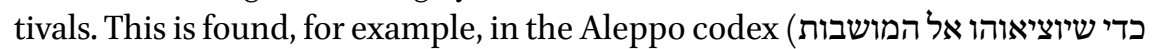
והקהלות שבעיר הקודש בשלשה רגלים חג המצות חג השבועות וחג הסוכות לקרות בו 'in order that they bring it [the codex] out to the settlements and communities in the holy city on the three pilgrimage festivals, the festival of Passover, the festival of Weeks and the festival Tabernacles to read in it'63), the Cairo Codex of

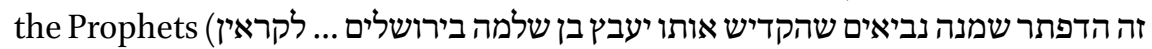
This is the codex, the Eight Prophets, which Ya'beș ben Shlomo consecrated in Jerusalem ... for the Karaites who celebrate the feasts at seeing the moon, for them all to

61 See Kahle, Masoreten des Westens I, 39; The Cairo Geniza, 2nd edition, 75-82.

62 See the document published by Mann, The Jews in Egypt and in Palestine, 2, 43-44.

63 Kahle, Masoreten des Westens II, 4. 
read on Sabbbath days, at new moons and at the feasts'64), Cod. 34 of the II

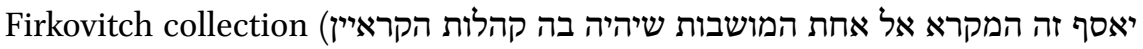
This Bible should be taken to one of the settlements in which there are Karaite communities on sabbaths and festivals in the city of Cairo so that the congregation can read it each sabbath and blessed festival'65). The use of masoretic codices for liturgical reading distinguished the Karaites from the Rabbanites, who continued to use scrolls for this purpose. ${ }^{66}$

The introduction of the codex in the Islamic period for the writing of Jewish scripture is likely to have been influenced by the use of the codex for the writing of the Qurān. This is reflected in the medieval Hebrew term for codex, viz. מצחף, which is clearly a loan of the Arabic term mușhaf. ${ }^{67}$ The use of the codex by the Karaites for liturgical reading can be interpreted as a reflection of a further rapprochement to the Islamic environment. The Rabbanites, by contrast, remained more conservative and restricted the codex to non-liturgical use.

\section{The Motivation for the Karaite Transcriptions}

The Arabic transcriptions of the Hebrew Bible reflect an even greater degree of rapprochement of the Karaites with the Muslim environment. They represent a convergence with the external form of the Muslim Arabic Qurān and also with the concepts of authority associated with the transmission of Muslim scripture. Unlike the Masoretic Bible codices, which were used by both Rabbanites and Karaites, these transcriptions were exclusive to the Karaites.

The authoritative written form of Muslim scripture was fixed in the early Islamic period. This was known as the Uthmanic text, since it was based on a

64 Kahle, The Cairo Geniza, 112-114. The Cairo Codex of the Prophets was preserved down to modern times in the Karaite synagogue in Cairo. The consecration to the Karaites of Jerusalem should be dated to the 11th century. This manuscript also has a colophon attributing it to the Masorete Moshe ben Asher, the father of Aharon ben Asher, with the date 895 C.E. There is now a consensus that the manuscript was written later, most likely in the 11th century, and this a later copy of an earlier colophon. For the arguments regarding its dating, see Cohen, "Has the Cairo Codex of the Prophets Indeed Been Written by Moshe b. Asher?"; Glatzer, "The Aleppo Codex-Codicological and Paleographical Aspects," 250259; Lipschütz, "Kitāb Al-Khilaf," 6-7.

65 Kahle, Masoreten des Westens II, no. 13, 74-77.

66 "Sefer ha-Torah ve-ha-Miṣhaf bi-Qri'at ha-Torah ba-Șibbur ba-'Adat ha-Rabbanim u-v'Adat ha-Qara'im."

67 Khan, A Short Introduction to the Tiberian Masoretic Bible and Its Reading Tradition, 6-7. 
codex (mușhaf) authorized by the caliph Uthman in the first century A.H./7th century C.E. To be precise, what was authorized was the rasm of the Uthmanic text, i.e. the shape of the letters, though not the diacritical points. In early Qur'ān manuscripts the diacritical points of the Arabic letters are, in fact, frequently omitted. Although the rasm became fixed, this could potentially be read in various ways and a variety of reading traditions (qiräāat) existed. The qir $\bar{a} a$ was regarded as the authoritative core of the text of scripture, which was based on the matrix of the rasm. It was crucially important, therefore, to establish principles for determining which qirä’ät were authoritative.

The early generations of Qur'ān readers felt a considerable amount of freedom in determining the reading of the Uthmanic fixed consonantal text. They often adopted one reading of the consonantal text rather than another on the basis of their judgment of its grammatical 'correctness', unconstrained by any other criteria. ${ }^{68}$ By the time of the Abbasid period, however, in the middle of the second century A.H., the freedom allowable in the choice of Qurannic readings began to be narrowed down. This was achieved by the introduction of two conditions for the selection of a reading, in addition to the requirement that it be grammatical and in conformity with the fixed consonantal text: the condition that the reading must be based on the normative usage of prestigious readers of earlier times, and that the reading must be agreed upon by a majority of readers. The two conditions were not necessarily mutually exclusive; they were both aspects of the concept of a generally agreed practice. The sources of authority for establishing the correct reading of the consonantal text of the Qur'ān which are recognized by Sībawayh (d. 18oA.H./796-797 C.E.) are those of the majority (qiräat al-ämma) and the model of former authoritative sources (al-sunna). He, in fact, identifies the one with the other, as is shown by his statement: al-qirāa lā tukăala liannahā al-sunna 'The reading [of the majority] is not to be disputed, because it is the normative usage. ${ }^{69}$ This expresses the view that the majority reading has religious sanction, since it is the normative ideal usage of the community. This notion of sunna and its merging with consensus is found also in the doctrine of the ancient schools of Islamic jurisprudence before al-Shāfīi (d. 204A.H./820 C.E.). ${ }^{70}$ Al-Farrā' (d. 207 A.H./822 C.E.) also regards the agreement of the majority of the readers and the traditions of the ancients as sources of authority for establishing the correct reading. When referring to these, he generally uses the terms 'ijtimāc and 'àtāarr.

68 Nöldeke, Bergsträsser, and Pretzl, Geschichte Des Qorans, 120; Beck, "Arabiyya, Sunna und 'Āmma in der Koranlesung des Zweiten Jahrhunderts," 188.

69 Derenbourg (ed.), Le Livre de Sibawaihi, 1, 62.

70 Schacht, The Origins of Muhammadan Jurisprudence, $5^{8-81 .}$ 
Throughout the third century A.H., the so-called 'majority principle' was widely used to establish the authoritative qiräa of the Qur'annic text. This was due mainly to the work of 'Abū 'Ubayd (d. 224/834) and 'Abū Ḥātim (Sahl ibn Muhammad) al-Sijistānī (d. 255/ 869). The application of the 'majority principle' in the selection of readings excluded those of small minorities. In cases where there was no agreement by a clear majority, 'Abū 'Ubayd, 'Abū Hâtim and others restricted their notion of 'majority' to that of the readers of specific centres, such as Medina and Küfa, or Medina and Mecca, or to that of specific readers, such as Nāfi' and 'Āṣim.

By the fourth century A.H., under the instigation of Ibn Mujāhid (d.324/936), the 'tradition principle,' whereby authority was given to the tradition of specific readers, began to replace the 'majority principle.' Ibn Mujāhid established seven canonical traditions of reading, which were endorsed by the ruling 'Abbāsid régime. ${ }^{71}$ These still fulfilled the requirements that they should conform to the rasm of the authoritative text, that they should be grammatically correct, and that they should be broadly authenticated. At a later period, the seven canonical traditions came to be accepted on the basis of their authoritative pedigree alone, in the manner of the principles of establishing the authority of hadith (traditions of the sayings of the prophet Muhammad). Ibn Mujāhid himself applied some degree of critical assessment of the content of the traditions, notably in their degree of grammatical correctness. ${ }^{72}$

We find eloquent evidence for the Karaites' convergence with Muslim thought regarding the transmission of scripture in the writings of the Karaite author al-Qirqisānī (first half of the tenth century C.E.). In a number of passages in his work Kitāb al-'Anwār w-al-Marāqib, he expresses his opinion about the basis of authority of Hebrew scripture. He makes it clear that the authority lies in the text represented by the reading tradition (qere) and not in that represented by the written tradition (ketiv). Moreover the reading tradition derives its authority from the agreement of the entire community ( $i j m \bar{a}^{c}$ ) and not from the authority of the sages or that of any specific group of people. The ketiv of the Hebrew Bible can be read in several different ways and the correctness of one reading rather than another can only be established by 'ijm $\bar{a}$. Furthermore in many cases reading the text on the basis of the written tradition blatantly results in the wrong meaning. ${ }^{73}$ For example, the frequent word נִ ְְרָ in the Pentateuch would be read as 'boy' rather than 'girl' if the ketiv is followed. The word

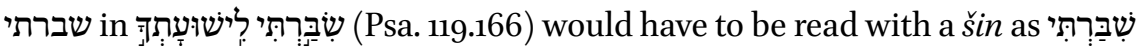

71 Ibn Mujāhid, Kitāb al-Sab'a fì al-Qirāààt ed. Cairo.

72 Nasser, "Revisiting Ibn Mujāhid's Position on the Seven Canonical Readings."

73 Nemoy (ed.), Kitab al-Anwār w-al-Marāqib, 2, 23.6. 
if the ketiv is the basis of the reading and the meaning would be 'I have broken' rather than 'I hope.' ${ }^{4}$

Al-Qirqisānī was aware of the fact that there were some differences in reading between the communities of Palestine and Iraq ('ahl al-Shām wa-'ahl alIrāq). In such cases the reading of the community of Palestine must have the supreme authority, even though the community of Iraq was larger. By the term 'ahl al-Shām al-Qirqisānī was referring to the Tiberian tradition of reading.

The position of al-Qirqisanī with regard to the biblical text, therefore, is as follows. The authoritative text of the Bible was represented by the reading tradition, which was validated by the 'ijm $\bar{a}$ ' of the entire nation ( $a l^{-}$'umma $)$in most of its details. Where there was no overriding consensus in the nation as a whole with regard to certain aspects of the tradition, it is the reading (qira $\bar{a} a$ ) of the Palestinians ('ahl al-shām) that was the correct and authoritative one. That is to say, the correct tradition in all its details is established by the 'ijm $\bar{a}^{c}$ of the 'ahl al-shäm rather than that of the nation as a whole. This has clear parallels to the overriding authority attributed to orally transmitted reading traditions (qirāa'at) of the Qur'ān and also to the notion that 'ijm $\bar{a}^{c}$ was a key determinant of the authority of a reading tradition.

Al-Qirqisāni’s advocacy of 'ijmma ' as a source of authority may have been further reinforced by the influence of Mu'tazili thought, which had a major impact on medieval Karaite thought in general at this period. ${ }^{75}$ The Mu'tazila rejected tradition as a source of law but accepted the validity of 'ijm $\bar{a}{ }^{c}{ }^{76}$ The Mu'tazili theologian 'Abd al-Jabbār (320/932 to 414-416/ 1023-1025) considered traditionalism (taqli d) to be an unsatisfactory way of acquiring knowledge, since it involved the uncritical acceptance of a report without demanding proof or evidence. ${ }^{77} \mathrm{He}$ maintained that $i j m \bar{a}{ }^{c}$, on the other hand, had probative value (hujjiyya). The probative value followed from the existence of ' $\ddot{j} m \bar{a}^{c}$. It does not require any proof that the information it conveys is true. ${ }^{78}$

74 In Rabbinic tradition the ketiv of the letter $\boldsymbol{w}$ was regarded as being $/ \check{s} /$ and its reading as /s/ was that of samek, which was considered to be the qere of this ketiv, i.e. the letter sin did not exist in the qere Steiner, "Ketiv-Kerē or Polyphony."

75 It is well known that the Karaites were influenced by many doctrines of Muslim Mu'tazili theologians. For Mu'talizī ideas elsewhere in al-Qirqisānī's Kitāb al-'Anwār, cf. BenShammai, "The Attitude of Some Early Karaites towards Islam," $27 \mathrm{ff}$.

76 Al-Šāfi'ì, Kitāb al-'Umm (Bulaq, 1321-1325/1903-07), 7:252-253; cf. Schacht, The Origins of Muhammadan Jurisprudence, 41, 258-259. Also Ibn al-Murtạ̣ā, Kitāb Ṭabaqāt al-Mu'tazila, ed. Diwald-Wilzer, 819, 952-4; 'Abd al-Jabbār, Kitāb Faḍl al-'Itizāl wa-Ṭabaqāt al-Mu'tazila, ed. Fu'ād Sayyid, 146-148.

77 Al-Mugin̄ fì 'Abwāb al-Tawhìd w-al-'Adl, ed. Ṭaha Ḥusayn, 12:123-126; Šarh al-'Ușūl alKamsa, ed. 'Abd al-Karīm 'Uțmān, 61.

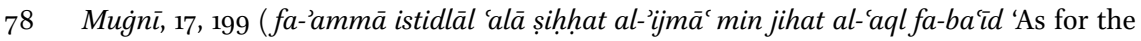


The adoption of the reading tradition as the overriding basis of authority had the consequence that the Hebrew Bible could not be considered to offer two sources of authority, one on the basis of the way it is read and the other on the basis of the way it is written. The interpretation of the Scripture on two levels, one according to the ketiv and one according to the qere was a practice that is found in Rabbinic sources. As shown by Naeh, ${ }^{79}$ this was a phenomenon that developed in the Talmudic period. It is reflected by the Talmudic dictum יש אם למקרא ויש אם למסורת The reading has authority and the traditional text has authority.' The details of the spelling of the written text, in particular the distribution of full and defective orthography, were used as a source for interpretation in various Rabbinic texts. ${ }^{80}$ According to the Midrash Genesis Rabbah, for example, there is exegetical significance as to why the second instance of the name Efron is spelled without a waw in the verse Gen. 23.16 whereas the first instance of the name in the verse and elsewhere in Gen. 23 has a waw:

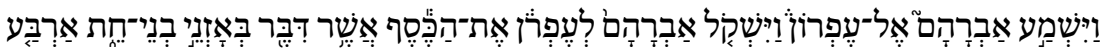

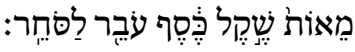

'Abraham agreed with Ephron; and Abraham weighed out for Ephron the silver which he had named in the hearing of the Hittites, four hundred shekels of silver, according to the weights current among the merchants.' (Gen. 23.16).

The lack of waw (ketiv haser) indicates that Efron will suffer want because he was envious and mean in accordance with the verse:

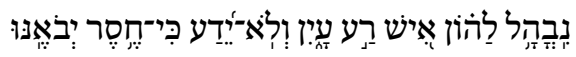

'A miserly man hastens after wealth, and does not know that want will come upon him.' (Prov. 28.22)

demonstration of the validity of ' $\dddot{i j m} \bar{a}^{\mathrm{c}}$ by reason, [this] is unconvincing/far-fetched.). Cf. Bernand “L'iğmā' chez 'Abd al-Ğabbār et l' objection d' an-Nazẓām”; idem, "Nouvelles Remarques sur l' iğmāc chez le Qāộ̄ ‘Abd al-Ǧabbār.”. A similar fideistic acceptance of the probative validity of ' $\ddot{j m m a} \bar{a}^{c}$ and the rejection of traditions is expressed by 'Abu al-Husayn al-Bașrī, who was the pupil of 'Abd al-Jabbār, cf. Kitāb al-Mu'tamad fì 'Ușül al-Figh, ed. Damascus, 457-540. Elsewhere 'Abd al-Jabbār states that 'ijmā' is supported by the Qur'ān and sunna, cf. Šarh, 89. The extreme rationalist Mu'tazali al-Nazzām and his school, however, had misgivings about the reliability of ' $i j m \bar{a}^{c}$, on the grounds that information has to be supported and ascertained before it can form the basis of ' $i j m \bar{a}$, i.e. ' $i j m \bar{a}$ ' is only the consequence of truth, not the source of truth, cf. 'Abd al-Qāhir ibn Ṭāhir al-Bag̉dādī, Kitāa 'Ușül al-Dīn, ed. Istanbul, 19-20.

79 "Did the Tannaim Interpret the Script of the Torah Differently from the Authorized Reading?"; "En Em Lammasoret—Second Time."

8o Goldberg, "The Rabbinic View of Scripture." 
In some cases such Midrashic texts exhibit a terminology and style of presentation that constitute embryonic Masoretic notes regarding differences in orthography of similar words. ${ }^{81}$ As has been remarked above, exegetical comments based on differences in orthography are indeed found embedded within the Masoretic notes in some of the Tiberian codices, e.g. the comment on the orthography of ?ריָּ (Job 8:8) in the Masorah of the Aleppo codex discussed by Zer. ${ }^{82}$

If the qere is the only source of authority, as is the opinion of al-Qirqisānī, then variations in orthography cannot be a legitimate source of authoritative exegesis, as in the comment on Job 8:8 in the Aleppo codex. So the representation of only the qere in the transcriptions reflects this polemical stance of the Karaites against this Midrashic style of exegesis. Furthermore, convergence with the Islamic model of scriptural authority would logically have resulted in the inconsistency between the ketiv and the qere being considered problematic. One of the key requirements of authoritative Qur'annic reading traditions at that period was that they conform to the rasm of the written text. This was clearly not the case in Hebrew scripture, in which the difference between ketiv and qere is sometimes very substantial, including reading whole words that are not written and writing whole words that are not read. The Hebrew Bible required a written rasm that corresponded to the reading tradition. The Karaite transcriptions of Hebrew Bibles represent the resolution of this tension by the abandonment of the traditional Hebrew written text and the provision of an acceptable rasm. The new rasm was created on the model of Islamic scripture in Arabic script. In addition to the use of Arabic script the manuscripts of the transcribed Bible exhibit a convergence with the Arabic Qurān in codicological features, such as the use of red ink to mark vocalization, the occasional use of Arabic vocalization signs and the insertion of ornamentation at various points on the page that resemble what is found in contemporary Qurān manuscripts. Moreover some manuscripts even use the Arabic word الله to represent the reading of the Tetragrammaton.

A few of the extant Karaite Bibles in Arabic script exhibit what is essentially a letter for letter transliteration of the Hebrew orthography rather than a phonetic transcription in Arabic orthography. It is likely that these are among the oldest manuscripts. The Hebrew matres lectionis, for example, are repro-

81 Martín Contreras, “Terminología masorética en la exégesis de Génesis rabba”; idem, "Noticias masoréticas en el midrás Lamentaciones Rabbâ"; idem, "Noticias masoréticas en los midrasim halákicos más antiguos y su comparación con los midrassim exegéticos."

"Was the Masorete of the Aleppo Codex of Rabbinite or Karaite Origin?" 
duced in Arabic script where they would not be appropriate according to Arabic orthography, e.g.

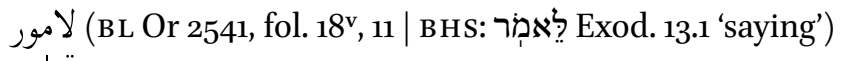

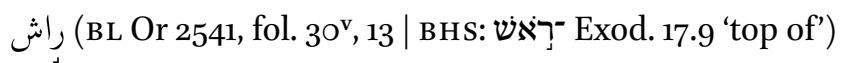

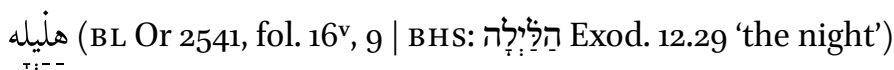

Conversely Arabic matres lectionis are not used when they are lacking in the Hebrew text even where they would be required in Arabic orthography to represent long vowels, e.g.

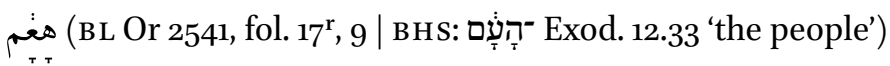

$$
\begin{aligned}
& \text { حن... (BL Or 2541, fol. 17 , } 2 \text { | BнS: Exod. } 12.36 \text { 'favour') }
\end{aligned}
$$

It is important to note, however, that such texts represent the qere in places where there is a conflict of qere and ketiv, e.g.

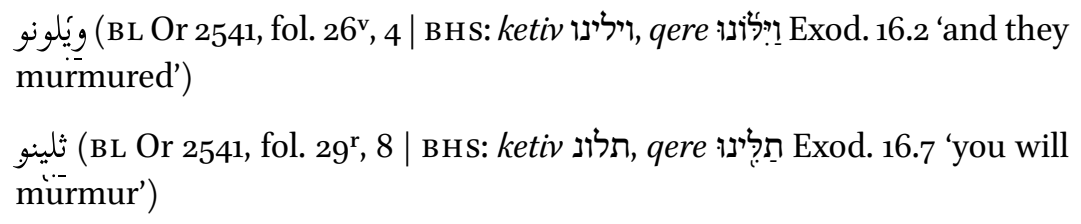

Moreover, there is a tendency to eliminate the inconsistency that is found in the distribution of the matres lectionis waw and yod of the Hebrew ketiv, to which exegetical significance was attached in Rabbinic sources. This is seen in the fact that in many contexts where waw and yod are inconsistently used in the Hebrew ketiv, the Arabic text more regularly uses the corresponding Arabic mater lectionis, wāw and $y \bar{a}$. This results in the Arabic matres lectionis being used in many cases where the Hebrew ketiv has defective orthography, e.g.

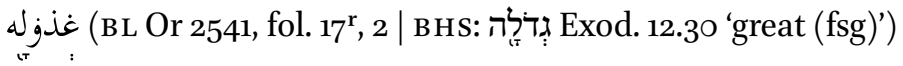

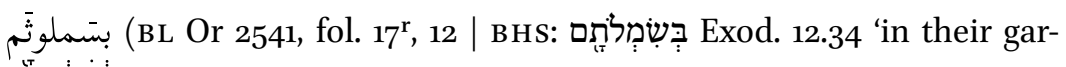
ments')

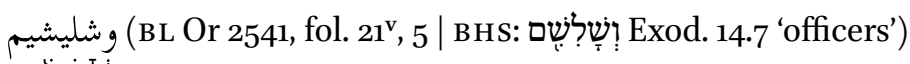

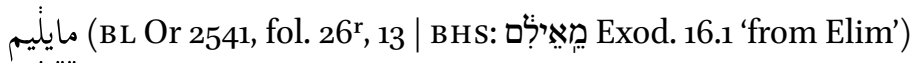


These early Karaite Bibles, therefore, attempted to produce a rasm that corresponded to the reading tradition and had an internal consistency.

The majority of extant Karaite Bibles in Arabic script, however, use a transcription system that is based essentially on the orthographic practices of Classical Arabic. These use matres lectionis to represent all long vowels, as is the practice in Arabic orthography. This appears to be a later development. Indeed a few manuscripts exhibit a hybrid system of orthography, which include features both of Hebrew orthography and Arabic orthography. These represent a transitional stage of development between the Hebrew type of orthography and the Arabic type of orthography, e.g.

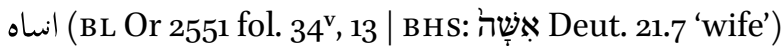

$$
\begin{aligned}
& \text { رواش (BL Or } 2539 \text { Ms B, fol. 115r, } 1 \text { | BHs: ראש Num. 6:18 'head') }
\end{aligned}
$$

In general the written transcription in the Karaite Bibles could not be read correctly without a knowledge of the reading tradition. This is shown by the fact that they often omit crucial details, such as diacritical points on the Arabic consonants. Moreover the spelling is often ambiguous. Each Arabic mater lectionis, for example, represents different qualities of Hebrew vowel.

The transcription manuscripts appear to have been produced for private use. The Bible manuscripts discussed above that have colophons indicating that they were deposited in Karaite synagogues for public liturgical reading are all large monumental codices in Hebrew script. The innovative use of Arabic script for Hebrew Bible manuscripts seems to have been restricted to private copies. This distinction in script between private and public copies of works is found also in medieval Karaite works written in Arabic language. A good example is the work on Hebrew grammar known as al-Kitāb al-Kāfi 'The Sufficient Book', which was written in Arabic in the first half of the 11th century by the Karaite 'Abū al-Faraj Hārūn. This is extant in numerous manuscripts. The manuscripts are almost exclusively written in Hebrew script. The surviving manuscripts include the autograph draft of the work by the author himself. It is significant that this private autograph manuscript is written in Arabic script. The other manuscripts appear to be published copies of the work. 83

In principle the traditional ketiv of Hebrew scripture could have been adjusted to conform to the qere without changing the script. Indeed this is found

83 Khan, Gallego, and Olszowy-Schlanger, The Karaite Tradition of Hebrew Grammatical Thought in Its Classical Form, xlvii-li. 
in some fragments of Bible manuscripts from this period that were written for private use and have been preserved in the Cairo Genizah. ${ }^{84}$ The adoption of the Arabic script in the Karaite transcriptions reflects a convergence with the external form of the Qurān, which was facilitated by the assignment of exclusive authority to the reading tradition.

The Islamic model required not only conformity of the reading to the rasm of the written text but also conformity of the reading to Arabic grammar. It was important for the Karaites, therefore, to legitimate the grammatical integrity of the Tiberian reading tradition. As has been remarked above, in the 1oth century a tradition of Karaite Hebrew grammatical thought emerged. The main source of our knowledge of this Karaite grammatical tradition in its early stages of development in the 1oth century is the grammatical commentary on the Bible by Yūsuf ibn Nūh known as the Diqduq. ${ }^{85}$ Ibn Nūh does not offer a systematic description of Hebrew grammar but rather concentrates on points that he believed may be problematic for the reader or concerning which there was controversy. One of the central concerns was to show that apparent inconsistencies in similar words can be explained as conforming to rational rules of grammar. This was often achieved by arguing that similar forms differing in small details were derived from different morphological bases. In the class of verbs which we refer to as final geminates, for example, there is variation in the position

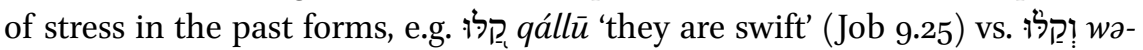
qallú 'and they are swift' (Hab. 1.8). According to Ibn Nūh this is not an arbitrary variation, but rather the forms with the penultimate stress are derived from a noun base whereas the forms with final stress have an imperative base. The Karaite grammarians were concerned only with the Tiberian reading tradition and did not take into account the ketiv. Their work vouchsafed the grammatical integrity of the reading tradition.

The Arabic transcriptions of the Hebrew Bible represent an extreme case of convergence with the Islamic environment. As has been remarked, there was variation in the Karaite community as to the degree of convergence. During the period in which the transcriptions were made, Karaites used also Hebrew script for both Arabic and Biblical Hebrew. Likewise there is evidence that some Karaites maintained the Talmudic principle of יש אם למקרא ויש אם למסורת (יחס The Karaite lexicographer David ben Abraham al-Fāsī (second half of the 1oth

84 Goshen-Gottstein, "Biblical Manuscripts in the United States," 39ff.; Díez-Macho, Manuscritos hebreos y arameos de la Biblia, 92; Yeivin Introduction to the Tiberian Masorah, 3031.

85 Khan, "The Book of Hebrew Grammar by the Karaite Joseph Ben Noah"; The Early Karaite Tradition of Hebrew Grammatical Thought. 
century), for example, cites this as a legitimate principle of exegesis in the introduction to his lexicon Kitāb Jāmic al-'Alfāz (ed. Skoss, I, 1-13). ${ }^{86}$

Of course, convergence with the culture of the Islamic environment was not unique to the Karaites. Rabbanites scholars of the 1oth and 11th centuries adopted the Arabic language in their writings and many elements of the Islamic intellectual tradition. This included a preference for the qere of the Hebrew Biblical. Saadya Gaon, for example, in principle follows the qere in his Arabic translations of the Bible and exegesis. The extent of the convergence, however, was to a lesser degree and this is reflected by the fact that they maintained Hebrew script in their writings.

\section{Acknowledgment}

I am grateful to Sarah Stroumsa for her helpful comments on an earlier draft of this paper.

\section{Bibliography}

'Abū al-Ḥusayn al-Bașrīi ibn Ḥusayn, Kitāb al-Mu'tamad fì 'Ușūl al-Fiqh, Damascus: alMa'had al-'Tlmī al-Faransī li-l-Dirāsāt al-'Arabīyah bi-Dimašq, 1384/1964.

'Abd al-Jabbār, 'Imād al-Dīn 'Abū al-Ḥasan ibn Ḥasan, Kitāb Faḍl al-'Itizāl wa-Ṭabaqāt al-Mu'tazila, ed. Fu'ād Sayyid, Beirut: Orient Institut, 2017.

'Abd al-Jabbār, 'Imād al-Dīn 'Abū al-Ḥasan ibn Ḥasan, Al-Mugnnī fí 'Abwāb al-Tawhìd w-al-'Adl, ed. Ṭaha Ḥusayn, Cairo: Wizārat al-Taqāāa w-al-'Iršād al-Qawmī, 138o1389/196o-69.

'Abd al-Jabbār, 'Imād al-Dīn 'Abū al-Ḥasan ibn Ḥasan, Šarh al-'Ușūl al-Kֵamsa, ed. 'Abd al-Karīm 'Uțmān, Cairo, 1384/1965.

'Abd al-Qāhir ibn Ṭāhir al-Bag̉dādī, Kitāb 'Ușūl al-Dīn, Istanbul: Mațba'at al-Dawlat, 1928/1346.

Allony, Nehemiah, "Rešimat Munahim Qara'it me-ha-Me’a ha-Šeminit," Kitve Ha-Hevra Le-Heqer Ha-Miqra be-Yisra'el le-Zexer Dr Y.P. Korngreen, ed. Asher Weiser and BenZion Luria, Tel-Aviv: Niv, 1964, pp. 324-363.

Allony, Nehemiah, "Sefer ha-Torah ve-ha-Miṣhaf bi-Qri'at ha-Torah ba-Șibbur ba-'Adat ha-Rabbanim u-v-'Adat ha-Qara'im," Beit Mikra 78 (1979), pp. 321-334.

86 It was also accepted by the Byzantine Karaite scholar Judah Hadassi (12th century); cf. Bacher, "Jehuda Hadassi's Hermeneutik Und Grammatik," 113. 
Al-Qirqisānī, Yacqūb ibn Isḥāq, Kitab Al-Anwār w-al-Marāqib, ed. Leon Nemoy. New York: The Alexander Kohut Memorial Foundation, 1939.

Al-Šāfi'ì, 'Abū 'Abdillāh Muhammad ibn 'Idrīs, Kitāa al-'Umm (Bulaq), 1321-1325/190307.

Bacher, Wilhelm, Die Anfänge der Hebräischen Grammatik und die Hebräische Sprachwissenschaft vom 10. bis zum 16. Jahrhundert, Amsterdam Studies in the Theory and History of Linguistic Science 4, Amsterdam: J. Benjamins, 1974.

Bacher, Wilhelm, "Jehuda Hadassi's Hermeneutik und Grammatik," Monatsschrift für Geschichte und Wissenschaft des Judentums 40 (1895), pp. 109-126.

Bacher, Wilhelm, Die Exegetische Terminologie der Jüdischen Traditionsliteratur, Leipzig: Hinrichs, 1899.

Baer, Seligmann, and Hermann Leberecht Strack, Die Dikduke Ha-Teamim des Ahron ben Moscheh ben Ascher und andere alte grammatisch-massoretische Lehrstücke, Leipzig: L. Pernoy, 1879 .

Beck, Edmund, "Arabiyya, Sunna und 'Āmma in der Koranlesung des Zweiten Jahrhunderts," Orientalia 15 (1946), pp. 18o-224.

Ben-Shammai, Haggai, "The Attitude of Some Early Karaites towards Islam," Studies in Medieval Jewish History and Literature, ed. Isadore Twersky, Cambridge, MA: Harvard University Press, 1984, 2, pp. 3-40.

Ben-Zvi, Izhak, "The Codex of Ben Asher," Textus 1 (1960), pp. 1-16.

Bernand, Marie, "L'iğmāe chez 'Abd al-Ǧabbār et l'objection d' an-Naẓāā," Studia Islamica 30 (1969), pp. 27-38.

Bernand, Marie, "Nouvelles Remarques sur l' iğmāc chez le Qāḍī 'Abd al-Ǧabbār." Arabica 19 (1972), pp. 78-85.

Blau, Joshua, and Simon Hopkins, "On Early Judaeo-Arabic Orthography," Zeitschrift für Arabische Linguistik 12 (1984), pp. 9-27.

Chiesa, Bruno, The Emergence of Hebrew Biblical Pointing: The Indirect Sources, Frankfurt: Lang, 1979 .

Cohen, Menahem, "Has the Cairo Codex of the Prophets Indeed Been Written by Moshe b. Asher?" Alei Sefer 10 (1982), pp. 5-12 (in Hebrew).

Derenbourg, Hartwig, Le Livre de Sîbawaihi; Traité de Grammaire Arabe. Vol. 1, Paris: Imprimerie Nationale, 1881.

Díaz Esteban, Fernando, Sefer 'Oklah Wě-'Oklah: Colección de Listas de Palabras Destinadas a Conservar la Integridad del Texto Hebreo de la Biblia entre los Judios de la Edad Media, Madrid: Consejo Superior de Investigaciones Científicas, 1975.

Díez Macho, Alejandro, Manuscritos hebreos y arameos de la Biblia: Contribución al Estudio de las Diversas Tradiciones del Texto del Antiguo Testamento, Rome: Institutum patristicum Augustinianum, 1971.

Dotan, Aron, The Diqduqé Hatțěamim of Ahăron Ben Moše Ben Ašér, Jerusalem: The Academy of the Hebrew Language, 1967 . 
Dotan, Aron, Dawn of Hebrew Linguistics: The Book of Elegance of the Language of the Hebrews, Jerusalem: ha-Iggud ha-'Olami le-Mada'e ha-Yahadut, 1997.

Dotan, Aron, Ben Asher's Creed: A Study of the History of the Controversy, Missoula, Mont.: Published by Scholars Press for the Society of Biblical Literature and the International Organization for Masoretic Studies, 1977.

Drory, Rina, Models and Contacts: Arabic Literature and its Impact on Medieval Jewish Culture, Leiden: Brill, 2000.

Drory, Rina, The Emergence of Jewish-Arabic Literary Contacts at the Beginning of the Tenth Century, Tel-Aviv: Tel-Aviv University, 1988 (in Hebrew).

Eldar, Ilan, “On Ben-Asher and Ben-Naftali," Lěšonénu 45 (1980), pp. 311-313 (in Hebrew). Eldar, Ilan, The Study of the Art of Correct Reading as Reflected in the Medieval Treatise Hidāyat Al-Qāri, Jerusalem: The Academy of the Hebrew Language, 1994 (in Hebrew).

Erder, Yoram, "Early Karaite Conceptions about Commandments Given before the Revelation of the Torah," Proceedings of the American Academy for Jewish Research 6o (1994), pp. 101-140.

Glatzer, Mordechai, "The Aleppo Codex-Codicological and Paleographical Aspects," Sefonot 4 (1989), pp. 167-276 (in Hebrew).

Goldberg, Arnold, "The Rabbinic View of Scripture," A Tribute to Geza Vermes. Essays on Jewish and Christian Literature and History, ed. Philip R. Davies and Richard T. White, Sheffield: Jsoт Press, 199o, pp. 153-166.

Goshen-Gottstein, Moshe, "The Authenticity of the Aleppo Codex," Textus 1 (1960), pp. $17-5^{8}$.

Goshen-Gottstein, Moshe, "Biblical Manuscripts in the United States," Textus 2 (1962), pp. $28-59$.

Gottheil, Richard, "Some Hebrew Manuscripts in Cairo," Jewish Quarterly Review 17 (1905), pp. 6o9-655.

Graetz, Heinrich, "Die Anfänge der Vocalzeichen im Hebräischen," Monatsschrift für Geschichte und Wissenschaft des Judentums 30 (1881), pp. 348-367.

Hadassi, Judah ben Elijah ha-Abel, Sefer 'Eshkol Ha-Kofer. Eupatoria: Mordechai Tirisken, 1836.

Harviainen, Tapani, "Abraham Firkovitsh, Karaites in Hìt, and the Provenance of Karaite Transcriptions of Biblical Hebrew Texts in Arabic Script," Folia Orientalia 28 (1991), pp. 179-191.

Harviainen, Tapani, "Karaite Bible Transcription with Indiscriminate Use of Tiberian Patah and Segol Vowel Signs," Semitica. Serta Philologica Constantino Tsereteli Dicata, ed. Riccardo Contini, Fabrizio Pennacchietti, and Mauro Tosco, Torino: Silvio Zamorani Editore, 1993, pp. 83-97.

Harviainen, Tapani, "Karaite Arabic Transcriptions of Hebrew in the SaltykovShchedrin Public Library in St. Petersburg," Estudios Masorericos. En Memoria de 
Harry M. Orlinsky, ed. Emilia Fernandez Tejero and María Teresa Ortega Monasterio, Madrid: Instituto de Filología del csic, 1993, pp. 63-72.

Harviainen, Tapani, "A Karaite Bible Transcription with Indiscriminate Counterparts of Tiberian Qameș and Holam (Ms. Firkovitsh II, Arab.-Evr. 1)," Proceedings of the Eleventh Congress of the International Organization for Masoretic Studies (IOMS), Jerusalem June 21-22, 1993, ed. Aron Dotan, Jerusalem: The World Union of Jewish Studies, 1994, pp. 33-40.

Harviainen, Tapani, "A Karaite Letter-for-Letter Transliteration of Biblical Hebrew-MS Firkovitsh II, Arab.-Evr. 355," Textus 18 (1995), pp. 196-177.

Harviainen, Tapani, "Ms Arab.-Evr. 2 of the Second Firkovitsh Collection, A Karaite Bible Transcription in Arabic Script," Studies in Hebrew and Jewish Languages Presented to Shelomo Morag, ed. Moshe Bar-Asher, Jerusalem: Bialik Institute, 1996, pp. ${ }^{*} 41-{ }^{*} 59$.

Harviainen, Tapani, "The Cairo Genizot and Other Sources of the Firkovich Collection in St. Petersburg," Proceedings of the Twelfth International Congress of the International Organization for Masoretic Studies, ed. E. John Revell, Atlanta, GA: Scholars Press, 1996, pp. 25-36.

Harviainen, Tapani, "Abraham Firkovich and the Karaite Community in Jerusalem in 1864," Manuscripta Orientalia 4 (1998), pp. 66-7o.

Hoerning, Reinhart, British Museum Karaite Mss. Descriptions and Collation of Six Karaite Manuscripts of Portions of the Hebrew Bible in Arabic Characters; with a Complete Reproduction ... of One, Exodus I. 1-VIII. 5, in ... Facsimiles, London: Williams and Norgate, 1889 .

Ibn Mujāhid, 'Aḥmad ibn Mūsā, Kitāb al-Sab'a fí al-Qirā’āt, ed. Shawqi Ḍayf, Cairo: Dār al-Ma'ārif, 1972.

Ibn al-Murtaḍā, Muḥammad ibn Yahyā, Kitāb Ṭabaqāt al-Mu'tazila, ed. Susanna Diwald-Wilzer, Beirut: Imprimerie Catholique, 1961.

Kahle, Paul, Masoreten des Westens I, Stuttgart: W. Kohlhammer, 1927.

Kahle, Paul, Masoreten des Westens II: Das Palästinische Pentateuch Targum, die Palätinische Punktation, der Bibeltext des Ben Naftali, Stuttgart: W. Kohlhammer, 1930.

Kahle, Paul, The Cairo Geniza. Schweich Lectures of the British Academy. London: Cumberlege [for the British Academy], 1947; second edition 1959.

Khan, Geoffrey, "Vowel Length and Syllable Structure in the Tiberian Tradition of Biblical Hebrew," Journal of Semitic Studies 32 (1987), pp. 23-82.

Khan, Geoffrey, Karaite Bible Manuscripts from the Cairo Genizah, Cambridge: Cambridge University Press, 1990.

Khan, Geoffrey, “The Medieval Karaite Transcriptions of Hebrew in Arabic Script," Israel Oriental Studies 12 (1992), pp. 157-176.

Khan, Geoffrey, "The Orthography of Karaite Hebrew Bible Manuscripts in Arabic Transcription," Journal of Semitic Studies 38 (1993), pp. 49-70. 
Khan, Geoffrey, "On the Question of Script in Medieval Karaite Manuscripts: New Evidence from the Genizah," Bulletin of the John Rylands University Library of Manchester 75 (1993), pp. 133-141.

Khan, Geoffrey, "The Book of Hebrew Grammar by the Karaite Joseph Ben Noah," Journal of Semitic Studies 43 (1998), pp. 265-286.

Khan, Geoffrey, The Early Karaite Tradition of Hebrew Grammatical Thought: Including a Critical Edition, Translation and Analysis of the Diqduq of 'Abū Ya'qūb Yüsuf Ibn Nūh on the Hagiographa, Leiden: Brill, 2000.

Khan, Geoffrey, "The Contribution of the Karaites to the Study of the Hebrew Language," A Guide to Karaite Studies: The History and Literary Sources of Medieval and Modern Karaite Judaism, ed. Meira Polliack, Boston: Brill, 2003, pp. 291-318.

Khan, Geoffrey, A Short Introduction to the Tiberian Masoretic Bible and Its Reading Tradition, 2nd edition, Piscataway, NJ: Gorgias, 2013.

Khan, Geoffrey, "The Medieval Karaite Tradition of Hebrew Grammar," A Universal Art. Hebrew Grammar Across Disciplines and Faiths, ed. Nadia Vidro, Irene E. Zwiep, and Judith Olszowy-Schlanger, Leiden: Brill, 2014, pp. 15-33.

Khan, Geoffrey, "The Relationship of 'Hidāyat Al-Qāri' to the Karaite Grammatical Tradition," Studies in Hebrew and Related Fields Presented to Ilan Eldar, ed. Moshe BarAsher and Irit Meir, Jerusalem: Karmel, 2014, pp. 277-283 (in Hebrew).

Khan, Geoffrey, "Judeo-Arabic," Handbook ofJewish Languages, ed. Lily Kahn and Aaron Rubin, Leiden-Boston: Brill, 2016, pp. 22-63.

Khan, Geoffrey, The Tiberian Pronunciation Tradition of Biblical Hebrew: Including a Critical Edition and English Translation of the Sections on Consonants and Vowels in the Masoretic Treatise Hidāyat al-Qāri' 'Guide for the Reader', 2 vols, Cambridge: University of Cambridge \& Open Book Publishers, 2020.

Khan, Geoffrey, María Ángeles Gallego, and Judith Olszowy-Schlanger, The Karaite Tradition of Hebrew Grammatical Thought in Its Classical Form: A Critical Edition and English Translation of al-Kitāb al-Kāfífì al-Luga al-Tbrāniyya by 'Abū al-Faraj Hārūn Ibn al-Faraj, Leiden: Brill, 2003.

Klar, Benjamin, Mehqarim ve-Tyyunim bi-Lšon ha-Širah u-v-Sifrut, ed. Abraham Meir Habermann, Tel-Aviv: Maḥbarot le-Sifrut, 1954.

Lipschütz, Lazar, Kitāb Al-Khilaf:Mishael Ben Uzziel's Treatise on the Differences between Ben Asher and Ben Naphtali, Jerusalem: Magnes, 1965.

Lipschütz, Lazar, "Kitāb Al-Khilaf, the Book of the Hillufim: Mishael Ben Uzziel's Treatise on the Differences between Ben Asher and Ben Napthali," Textus 4 (1964), pp. 2 29.

Mann, Jacob, The Jews in Egypt and in Palestine under the Fātimid Caliphs, reprint, vol. 2, Oxford: Oxford University Press, 1969.

Mann, Jacob, Texts and Studies in Jewish History and Literature, vol. 2, Cincinnati:Jewish Publication Society, 1935 . 
Margoliouth, George, “Ibn Al-Hītī's Arabic Chronicle of Karaite Doctors," Jewish Quarterly Review 9 (1897), pp. 429-443.

Martín Contreras, Elvira, "Terminología Masorética en la Exégesis de Génesis Rabba (secciones 'Bere'sit' y Noah')," Sefarad 59 (1999), pp. 343-352.

Martín Contreras, Elvira, "Noticias masoréticas en el Midrás 'Lamentaciones Rabbâ,"” Sefarad 62 (2002), pp. 125-141.

Martín Contreras, Elvira, "Noticias Masoréticas en los Midrasim Halákicos más Antiguos y su Comparación con los Midrassim Exegéticos," Sefarad 63 (2003), pp. 119-139.

Naeh, Shlomo, "Did the Tannaim Interpret the Script of the Torah Differently from the Authorized Reading?” Tarbiz 61 (1992), pp. 401-448 (in Hebrew).

Naeh, Shlomo, "En Em Lammasoret—Second Time," Tarbiz 62 (1993), pp. 455-462 (in Hebrew).

Nasser, Shady Hekmat, "Revisiting Ibn Mujāhid's Position on the Seven Canonical Readings: Ibn 'Āmir's Problematic Reading of Kun Fa-Yakūna," Journal of Qur'anic Studies 17 (2015), pp. 85-113.

Nöldeke, Theodor, Gotthelf Bergsträsser, and Otto Pretzl, Geschichte des Qorans. 2nd edition, part 3, Leipzig: Dieterichsche Verlagsbuchhandlung, 1938.

Ofer, Yosef. “M.D. Cassuto's Notes on the Aleppo Codex." Sefunot 68 (1989), pp. 277-344. Ognibeni, Bruno, La Seconda Parte del Sefer'Oklah We'Oklah:Edizione delMs. Halle, Universitätsbibliothek Y B 40 10, Ff. 68-124, Madrid-Fribourg: Instituto de Filología del csic, Departamento de Filología Bíblica y de Oriente Antiguo; Université Fribourg, 1995.

Outhwaite, Ben, "Beyond the Leningrad Codex: Samuel b. Jacob in the Cairo Genizah," Studies in Semitic Linguistics and Manuscripts: A Liber Discipulorum in Honour of Professor Geoffrey Khan, ed. Vidro, Nadia, Ronny Vollandt, Esther-Miriam Wagner, and Olszowy-Schlanger, Uppsala University Library, 2018, pp. 320-340.

Penkower, Jordan, "A Tenth-Century Pentateuchal ms from Jerusalem (Ms C3), Corrected by Mishael Ben Uzziel," Tarbiz $5^{8}$ (1989), pp. 49-74 (in Hebrew).

Penkower, Jordan, “Maimonides and the Aleppo Codex," Textus 9 (1981), pp. 39-128.

Phillips, Kim, "A New Codex from the Scribe behind the Leningrad Codex: L17," Tyndale Bulletin 68 (2017), pp. 1-29.

Pinsker, Simhah, Lickute Kadmoniot. Zur Geschichte des Karaismus und der karaïschen Literatur, Wien, 186o.

Poznanski, Samuel, "Reshit hityashvut ha-qara'im b-Irushalayim," ed. Abraham Moses Luncz. Jerusalem 10 (1913), pp. 83-116.

Sáenz-Badillos, Ángel, Tešubot de Dunaš ben Labrat: edición crítica y traducción española, Granada: Universidad de Granada, 1980.

Schacht, Joseph, The Origins of Muhammadan Jurisprudence, Oxford: Clarendon Press, $195^{\circ}$. 
Steiner, Richard, "Ketiv-Kerē or Polyphony: The ש-ש Distinction According to the Masoretes, the Rabbis, Jerome, Qirqisānī, and Hai Gaon," Studies in Hebrew and Jewish Languages Presented to Shelomo Morag, ed. Moshe Bar-Asher, Jerusalem: Bialik Institute, 1996 , pp. * $151^{-{ }^{*}} 179$.

Stroumsa, Sarah, "The Muslim Context of Medieval Jewish Philosophy," The Cambridge History of Jewish Philosophy: From Antiquity through the Seventeenth Century, ed. Steven M. Nadler and Tamar Rudavsky, Cambridge: Cambridge University Press, 20o9, pp. 39-59.

Tirosh-Becker, Ofra, Rabbinic Excerpts in Medieval Karaite Literature, 2 vols, Jerusalem: Bialik Institute and the Hebrew University, 2011 (in Hebrew).

Vidro, Nadia, "Verbal Morphology in the Karaite Treatise on Hebrew Grammar Kitāb Al'Uqūd Fī Tașāinf al-Lug̉a al-'Ibrāniyya," Ph.D. thesis, University of Cambridge, 2009. Vidro, Nadia, Verbal Morphology in the Karaite Treatise on Hebrew Grammar: Kitāb al'Uqūd fi Tașārīf al-Luġa al-Ibrāniyya, Leiden: Brill, 2011.

Yeivin, Israel, Introduction to the Tiberian Masorah, Missoula: Scholars Press, 198o.

Yeivin, Israel, "The Vocalization of Qere-Kethiv in A," Textus 2 (1962), pp. 146-149.

Zer, Rafael Isaac, "Was the Masorete of the Aleppo Codex of Rabbinite or Karaite Origin?" Sefunot 8 (2003), pp. 573-587.

Zucker, Moshe, "Against Whom Did Se'adya Ga'on Write the Polemical Poem 'Essa Meshali'?" Tarbiz 27 (1958), pp. 61-82 (in Hebrew). 